\title{
PEMANFAATAN TEPUNG IKAN PORA-PORA (Mystacoleucus Padangensis) SEBAGAI SUBSTITUSI TEPUNG IKAN KOMERSIAL DALAM RANSUM TERHADAP PERFORMANS ITIK PORSEA
}

\author{
Utilization of Pora-Pora Fishmeal (Mystacoleucus padangensis) to Substitute Commercial \\ Fishmeal in Diet on Performances of Porsea Ducks
}

\author{
Fazawao Zega ${ }^{1}$, Tri Hesti Wahyuni ${ }^{2}$ dan Nurzainah Ginting ${ }^{2}$
}

1. Mahasiswa Program Studi Peternakan Fakultas Pertanian Universitas Sumatera Utara

2. Staf Pengajar Program Studi Peternakan Fakultas Pertanian Universitas Sumatera Utara

\begin{abstract}
Pora-pora Fish is one type of fish found in the waters of Toba Lake and sold by traders in traditional markets around Toba Lake. Research was conducted at the Laboratory Animal Sciences Study Program, Faculty of Agriculture, University of Sumatera Utara, starting in September to November 2014. This study used 100 heads day old Porsea ducks and design used was a completely randomized design (CRD) consisted of 5 treatments 4 replications and each replication consisted of 5 heads day old Porsea ducks. Level substitution of commercial fishmeal by pora-pora fishmeal with ration P0 (0:100); P1 (25:75); P2 (50:50); P3 (75:25) and P4 (100:0). The results showed that the utilization of pora-pora fishmeal significantly different effect $(P<0,05)$ on feed consumption (g/head/week): (510,35; 520,75; 521,43; 519,41 and 518,46, respectively), body weight gain (g/head/week): (131,34; 135,57; 136,79; 132,08 and 116,43, respectively) and not significantly different effect $(P>0,05)$ on feed conversion ration $(F C R)$. The conclusion of this research is utilization of pora-pora fishmeal can substitute $75 \%$ of commercial fishmeal.
\end{abstract}

Keywords: Performance, Porsea duck, pora-pora fishmeal, commercial fishmeal

\begin{abstract}
ABSTRAK
Ikan pora-pora adalah salah satu jenis ikan yang terdapat di perairan Danau Toba dan dijual oleh para pedagang di pasar tradisional khususnya di sekitar perairan Danau Toba. Penelitian telah dilaksanakan di Laboratorium Biologi Ternak Program Studi Peternakan, Fakultas Pertanian, Universitas Sumatera Utara selama 3 bulan, dimulai bulan September - November 2014. Penelitian ini menggunakan 100 ekor day old duck (DOD) itik porsea dan rancangan yang digunakan adalah rancangan acak lengkap (RAL) yang terdiri atas 5 perlakuan 4 ulangan dan setiap ulangan teridiri dari 5 ekor DOD. Level substitusi tepung ikan komersial oleh tepung ikan pora-pora dalam ransum adalah PO (0:100); P1 (25:75); P2 (50:50); P3 (75:25) dan P4 (100:0). Hasil penelitian menunjukkan bahwa pemanfaatan tepung ikan pora-pora memberikan pengaruh berbeda nyata $(\mathrm{P}<0,05)$ terhadap konsumsi pakan (g/ekor/minggu) berturut-turut: $(510,35 ; 520,75 ; 521,43 ; 519,41$ dan 518,46$)$, pertambahan bobot badan (g/ekor/minggu) berturut-turut: $(131,34 ; 135,57 ; 136,79 ; 132,08$ dan 116,43) dan tidak berbeda nyata $(\mathrm{P}>0,05)$ terhadap konversi pakan. Kesimpulan dari penelitian ini adalah pemanfaatan tepung ikan pora-pora dapat menggantikan tepung ikan komersial sebesar $75 \%$.
\end{abstract}

Kata kunci: Performan, itik porsea, tepung ikan pora-pora, tepung ikan komersial.

\section{PENDAHULUAN}

Pertumbuhan ekonomi di Indonesia saat ini memicu masyarakat untuk memenuhi kebutuhan nutrisi yang baik, antara lain protein. Protein hewani sampai saat ini digemari oleh masyarakat baik protein dari ternak ruminansia besar, menengah, kecil maupun protein hewani asal unggas. Salah satu unggas yang mulai digemari masyarakat adalah itik. 
Wasito dan Eni (1994) menyatakan bahwa pemeliharaan itik masih banyak dilakukan secara tradisional, berbeda dengan pemeliharaan ayam yang telah berkembang pesat, sesuai dengan perkembangan teknologi. Pemeliharaan itik masih terbatas pada daerah-daerah yang keadaan alamnya masih memungkinkan, seperti daerah rawa, danau, pinggiran sungai, persawahan yang luas. Keadaan ini menyebabkan produktivitas atau populasi tidak stabil.

Penanganan ternak itik yang kurang bagus dapat menyebabkan pertumbuhan yang sangat lambat dan bahkan dapat menyebabkan kematian ternak itu sendiri sehingga menyebabkan kerugian besar bagi peternaknya. Kekurangan tersebut dapat diatasi dengan menyediakan pakan yang berkualitas.

Perkembangan ternak itik di Kabupaten Toba Samosir memiliki prospek yang sangat cerah, hal ini dapat diketahui dari data yang menyebutkan bahwa jumlah ternak itik di Kabupaten Toba Samosir yang tersebar di 16 kecamatan berjumlah 180.410 ekor. Sedangkan di Kecamatan Porsea sendiri berjumlah 18.113 ekor pada tahun 2012 ( BPS Kabupaten Toba Samosir, 2013).

Pakan merupakan salah satu faktor penting dalam melaksanakan kegiatan usaha peternakan. Umumnya biaya pakan adalah salah satu faktor terbesar yang dikeluarkan dalam kegiatan usaha peternakan. Pada pola pemeliharaan intensif, biaya produksi ternak terbesar berasal dari pakan yaitu sebesar 60-70\%. Dengan kemajuan ilmu dan teknologi di bidang peternakan sangat penting untuk menghasilkan pakan alternatif lain yang berpotensi dalam usaha menekan penggunaan pakan komersial yang membutuhkan biaya yang besar sehingga para peternak dapat memperoleh untung yang lebih besar. Salah satunya adalah dengan memanfaatkan tepung ikan yang tersedia lokal.

Tepung ikan adalah sumber bahan makanan yang berprotein tinggi dan sangat baik bagi ternak itik. Secara keseluruhan tepung ikan mengandung protein tinggi antara 50-70\%. Selain protein, tepung ikan juga memiliki kandungan gizi yang lain seperti kalsium dan fosfor. Semuanya ini sangat baik untuk menunjang daya pertumbuhan dari ternak itik.

Tepung ikan merupakan salah satu produk perikanan yang diperlukan dalam jumlah yang tinggi di Indonesia, terutama dalam memasok kebutuhan industri pakan ternak, ikan dan udang. Tepung ikan mengandung senyawa-senyawa esensial yang dibutuhkan untuk pertumbuhan oleh ternak. Senyawa-senyawa tersebut antara lain: protein, asam lemak omega 3, vitamin dan mineral. Senyawa-senyawa tersebut juga sangat berperan penting dalam masa pertumbuhan itik (Sihaloho, 2014). 
Ikan pora-pora adalah salah satu jenis ikan yang terdapat di perairan Danau Toba dan dijual oleh para pedagang di pasar tradisional khususnya di sekitar perairan Danau Toba (Kartamihardja, 2009). Dikarenakan palatabilitas Ikan Pora-pora secara relatif kurang disukai dibanding ikan lain yang diproduksi komersial di Danau Toba seperti Ikan Nila ataupun Mujair maka harga Ikan Pora-pora tidak stabil.

Pada saat hasil tangkapan berlebihan dari para nelayan maka terjadi over supply sehingga harga Ikan Pora-pora menjadi sangat murah yaitu sekitar Rp. 500/kg (Dinas Pertanian Karo, 2012). Akibatnya nelayan tidak tertarik menangkap Ikan Pora-pora. Hal ini sangat disayangkan karena Ikan Pora-pora masih mempunyai potensi untuk diolah menjadi tepung ikan yang merupakan sumber protein bagi ternak komersil misalnya.

Indonesia banyak mengimpor tepung ikan dari Brazilia. Hal ini akan membawa dampak terhadap devisa Indonesia. Bila impor tepung ikan dapat dikurangi dengan memanfaatkan tepung ikan lokal maka merupakan suatu terobosan yang baik bagi perekonomian Indonesia. Pemaparan di atas penulis tertarik dalam memanfaatkan ikan porapora dan mengetahui pengaruh pemberian ikan pora-pora dalam ransum itik porsea umur 012 minggu.

\section{BAHAN DAN METODE PENELITIAN}

\section{Tempat dan Waktu Penelitian}

Penelitian dilaksanakan di Laboratorium Biologi Ternak Program Studi Peternakan Fakultas Pertanian Universitas Sumatera Utara. Penelitian ini dilaksanakan selama 3 bulan yaitu bulan Septrmber 2014 sampai bulan November 2014.

\section{Bahan dan Alat Penelitian}

\section{Bahan}

Bahan yang digunakan dalam penelitian adalah 100 ekor day old duck (DOD) $(40,81 \pm 3,2$ gram) itik porsea sebagai objek penelitian, ransum komersil, ransum yang disusun terdiri dari tepung jagung, dedak sebagai sumber energi, tepung ikan komersil, tepung ikan pora-pora yang diolah dari sortiran produksi, bungkil kelapa dan bungkil kedelai sebagai sumber protein dan kalsium, topmix sebagai sumber vitamin, obat-obatan, rodalon sebagai desinfektan dan air minum diberikan secara ad libitum. 


\begin{abstract}
Alat
Alat yang digunakan dalam penelitian adalah kandang dengan ukuran 1 x 1 x 0,5 meter sebanyak 20 unit beserta perlengkapannya, timbangan untuk menimbang bobot badan hidup dan menimbang pakan berkapasitas $5 \mathrm{~kg}$ dengan kepekaan $2 \mathrm{~g}$, alat pembuatan tepung ikan (kompor, panci presto dan sendok), alat kebersihan (ember, sapu lidi, kereta sorong dan sekop), termometer untuk mengetahui suhu di dalam dan di luar kandang, alat penerangan kandang, terpal untuk menutup dinding kandang, alat tulis dan kalkulator untuk pengambilan data.
\end{abstract}

\title{
Metode Penelitian
}

Metode penelitian yang digunakan adalah rancangan acak lengkap (RAL) yang terdiri dari 4 perlakuan dan 5 ulangan. Adapun susunan perlakuan yang diberikan adalah sebagai berikut:

$\mathrm{P} 0=$ Ransum dengan $10 \%$ tepung ikan komersial

$\mathrm{P} 1=$ Ransum dengan 7,5\% tepung ikan komersial $+2,5 \%$ tepung ikan pora-pora

$\mathrm{P} 2=$ Ransum dengan 5\% tepung ikan komersial $+5 \%$ tepung ikan pora-pora

$\mathrm{P} 3=$ Ransum dengan 2,5\% tepung ikan komersial $+7,5 \%$ tepung ikan pora-pora

$\mathrm{P} 4=$ Ransum dengan $10 \%$ tepung ikan pora-pora

\section{Analisis Data}

Data yang diperoleh dianalisis secara statistik dengan menggunakan sidik ragam sesuai Rancangan Acak Lengkap (RAL) dengan 5 perlakuan dan 4 ulangan.

\section{Paramater Penelitian}

\section{Konsumsi Pakan}

Konsumsi ransum dihitung setiap hari berdasarkan selisih antara ransum yang diberikan dengan jumlah sisa ransum. Dapat dirumuskan sebagai berikut :

Konsumsi Ransum =

Ransum Awal - Ransum Sisa (Parakkasi, 1999).

\section{Pertambahan Bobot Badan}

Pertumbuhan umumnya dinyatakan dengan pengukuran kenaikan bobot melalui penimbangan berulang-ulang yaitu, setiap hari, setiap minggu, atau setiap waktu lainnya (Tillman et al., 1991). Dengan rumus sebagai berikut : 
Pertambahan Bobot Badan $($ PBB $)=$ Bobot badan akhir - bobot badan awal

\section{Konversi Ransum}

Konversi ransum adalah unit ransum yang diperlukan untuk menghasilkan unit pertambahan bobot badan (North dan Bell, 1990). Dengan rumus sebagai berikut:

Konversi Ransum $=\frac{\text { Konsumsi Pakan }}{\text { Pertambahan Bobot Badan }}$

\section{Susunan nutrisi ransum percobaan penelitian}

Tabel 1. Kandungan Nutrisi Bahan Penyusun Ransum

\begin{tabular}{lrrrr}
\hline \multirow{2}{*}{ Bahan Pakan } & \multicolumn{4}{c}{ Kandungan Nutrisi } \\
\cline { 2 - 5 } & EM (kkal/kg) & PK (\%) & LK (\%) & SK (\%) \\
\hline T. Ikan Komersial & $2.810^{\mathrm{b}}$ & $52,60^{\mathrm{a}}$ & $4,80^{\mathrm{b}}$ & $2,20^{\mathrm{a}}$ \\
T. Ikan Pora-pora & $2.973^{\mathrm{c}}$ & $50,94^{\mathrm{c}}$ & $13,24^{\mathrm{c}}$ & $0,37^{\mathrm{c}}$ \\
T. Jagung & $3.420^{\mathrm{b}}$ & $8,30^{\mathrm{a}}$ & $3,90^{\mathrm{b}}$ & $2,20^{\mathrm{a}}$ \\
Bungkil Kedelai & $2.240^{\mathrm{a}}$ & $43,80^{\mathrm{b}}$ & $1,50^{\mathrm{b}}$ & $4,40^{\mathrm{a}}$ \\
Dedak & $2.850^{\mathrm{b}}$ & $13,30^{\mathrm{b}}$ & $7,20^{\mathrm{d}}$ & $13,50^{\mathrm{a}}$ \\
Bungkil Kelapa & $1.540^{\mathrm{b}}$ & $21,00^{\mathrm{d}}$ & $6,70^{\mathrm{d}}$ & $15,00^{\mathrm{d}}$ \\
\hline Sumber: a. Hartadi et al., (1997) & \multicolumn{4}{c}{} \\
\multicolumn{4}{c}{ b. NRC (1994) } \\
\multicolumn{2}{c}{ c. Laboratorium Loka penelitian Kambing Potong, Sei Putih (2013) } \\
$\quad$ d. Laboratorium Ilmu Nutrisi dan Pakan Ternak, FP USU (2008).
\end{tabular}

Susunan nutrisi ransum percobaan penelitian adalah seperti di bawah ini.

Tabel 2. Susunan Nutrisi Ransum Percobaan Untuk Umur 0-2 Minggu

\begin{tabular}{llrrrrr}
\hline Nutrisi* & P0 & P1 & P2 & P3 & P4 \\
\hline 1 & Protein Kasar & 21,56 & 21,46 & 21,42 & 21,38 & 21,34 \\
2 & Energi Metabolisme & 2908,50 & 2912,58 & 2916,65 & 2920,72 & 2924,80 \\
3 & Lemak Kasar & 3,61 & 3,82 & 4,03 & 4,24 & 4,45 \\
4 & Serat Kasar & 3,58 & 3,53 & 3,49 & 3,44 & 3,40 \\
5 & Posfor & 0,60 & 0,57 & 0,54 & 0,52 & 0,50 \\
6 & Kalsium & 6,74 & 5,20 & 3,65 & 2,11 & 0,56 \\
\hline
\end{tabular}

*Perhitungan berdasarkan kandungan nutrisi bahan penyusun ransum

Tabel 3. Susunan Nutrisi Ransum Percobaan Untuk Umur 3-12 Minggu

\begin{tabular}{clrrrrr}
\hline Nutrisi* & P0 & P1 & P2 & P3 & \multicolumn{1}{c}{ P4 } \\
\hline 1 & Protein Kasar & 16,70 & 16,65 & 16,61 & 16,57 & 16,53 \\
2 & Energi Metabolisme & 2978,10 & 2982,17 & 2986,25 & 2990,32 & 2994,40 \\
3 & Lemak Kasar & 4,43 & 4,64 & 4,85 & 5,06 & 5,27 \\
4 & Serat Kasar & 4,66 & 4,61 & 4,56 & 4,52 & 4,47 \\
5 & Posfor & 0,77 & 0,75 & 0,72 & 0,70 & 0,68 \\
6 & Kalsium & 6,70 & 5,16 & 3,61 & 2,07 & 0,52 \\
\hline \multicolumn{7}{l}{ * Perhitungan berdasarkan kandungan nutrisi bahan penyusun ransum }
\end{tabular}




\section{Konsumsi Ransum}

Konsumsi ransum adalah jumlah ransum yang dimakan dalam jangka waktu tertentu dengan tujuan agar ternak dapat hidup, meningkatkan pertumbuhan bobot badan ternak dan berproduksi. Pengambilan data konsumsi ransum itik Porsea dilakukan setiap minggunya, data konsumsi ransum diperoleh dengan cara melakukan penimbangan ransum sisa yang dilakukan setelah seminggu. Data hasil pengamatan terhadap rataan konsumsi ransum itik Porsea dapat dilihat pada Tabel 3.

Tabel 3 dapat dilihat bahwa rataan konsumsi ransum itik Porsea tertinggi terdapat pada P2 (521,43 g/ekor/minggu $)$ kemudian diikuti P1 (520,75 g/ekor/minggu), P3 (519,41 g/ekor/minggu) P4 (518,46 g/ekor/minggu) dan terendah terdapat pada P0 sebesar 510,35 g/ekor/minggu.

Tabel 3 menunjukkan bahwa rataan konsumsi ransum Itik Porsea secara umum sebesar 518,08 gram/ekor/minggu. Angka tersebut lebih rendah daripada pemeliharaan itik raja menurut Pasaribu (2011) yaitu rata-rata 552,82 gram/ekor/minggu. Hal ini disebabkan perbedaan jenis atau genetik ternak tersebut, sesuai dengan pernyataan Piliang (2000) yang menyatakan bahwa konsumsi ransum dipengaruhi oleh beberapa faktor diantaranya adalah palatabilitas ransum, bentuk fisik ransum, bobot badan, jenis kelamin, genetik, temperatur lingkungan, keseimbangan hormonal dan fase pertumbuhan.

Tabel 3. Rekapitulasi data performans Itik Porsea

\begin{tabular}{llll}
\hline Perlakuan & Konsumsi (g/ekor/mg) & PBB (g/ekor/mg) & Konversi \\
\hline P0 & $510,35^{\mathrm{b}} \pm 9,66$ & $131,34^{\mathrm{a}} \pm 2,14$ & $3,91^{\mathrm{tn}} \pm 0,24$ \\
P1 & $520,75^{\mathrm{a}} \pm 2,87$ & $135,57^{\mathrm{a}} \pm 8,01$ & $3,96^{\mathrm{tn}} \pm 0,19$ \\
P2 & $521,43^{\mathrm{a}} \pm 1,93$ & $136,79^{\mathrm{a}} \pm 15,15$ & $3,89^{\mathrm{tn}} \pm 0,43$ \\
P3 & $519,41^{\mathrm{a}} \pm 2,10$ & $132,08^{\mathrm{a}} \pm 8,63$ & $4,07^{\mathrm{tn}} \pm 0,27$ \\
P4 & $518,46^{\mathrm{a}} \pm 2,73$ & $116,43^{\mathrm{b}} \pm 3,87$ & $4,49^{\mathrm{tn}} \pm 0,28$ \\
\hline Rataan & 518,08 & 130,44 & 4,06 \\
\hline
\end{tabular}

Ket. Huruf yang berbeda pada kolom yang sama menunjukksan berbeda nyata $(\mathrm{P}<0,05)$ tn : tidak nyata $(\mathrm{P}>0,05)$

Berdasarkan hasil analisis ragam menunjukkan bahwa ransum perlakuan dengan perbedaan tepung ikan dalam level yang sama menyebabkan perbedaan yang nyata $(\mathrm{P}<0,05)$ pada tingkat konsumsi ransum Itik Porsea. Ransum yang 
paling rendah dikonsumsi adalah perlakuan P0 yaitu ransum $+10 \%$ tepung Ikan Pora-pora.

Hasil uji lanjut dengan Duncan menunjukkan bahwa perlakuan P1, P2, P3 dan P4 berbeda nyata dengan perlakuan P0. Hal ini dikarenakan aroma tepung ikan yang seimbang antara tepung ikan komersial dan tepung ikan pora-pora yang diberikan kepada ternak yang menyebabkan palatabilitas ternak terhadap perlakuan P1, P2, P3 dan P4. Tetapi pada perlakuan P0, yaitu pemberian tepung ikan komersial 100\% tingkat konsumsi ternak menurun karena aroma tepung ikan komersial yang pekat sehingga menyebabkan aroma bahan penyusun ransum lainnya tidak muncul. Hal ini sesuai dengan pernyataan Willamson dan Payne (1993) yang mengatakan bahwa pengukuran konsumsi ransum dipengaruhi oleh perbedaan ternak, palatabilitas ransum dan seleksi terhadap ransum.

Konsumsi ransum juga mempunyai hubungan dengan kebutuhan energi ternak yang sering menyebabkan konsumsi ransum ternak menjadi berbeda. Pemberian ransum secara ad libitum juga memberikan pengaruh pada konsumsi ransum sehingga ternak tidak mengalami penurunan konsumsi. Parakkasi (1999) menyatakan bahwa konsumsi pakan adalah jumlah pakan yang dikonsumsi oleh hewan apabila bahan pakan tersebut diberikan secara ad libitum. Jumlah konsumsi pakan merupakan faktor penentu paling penting dalam menentukan jumlah nutrien yang didapat oleh ternak dan pengaruh terhadap tingkat produksi ternak.

\section{Pertambahan Bobot Badan}

Pertambahan bobot badan Itik Porsea dalam penelitian ini diperoleh dari hasil penimbangan bobot badan akhir dikurangi dengan bobot badan awal penimbangan. Penimbangan bobot badan dilakukan satu kali dalam seminggu. Data hasil pengamatan pertambahan bobot badan Itik Porsea dapat dilihat pada Tabel 3. Tabel 3 menunjukkan bahwa rata-rata pertambahan bobot badan tertinggi yaitu pada perlakuan P2 (136,79 g/ekor/minggu), kemudian diikuti perlakuan P1 (135,57 g/ekor/minggu), P3 (132,08 g/ekor/minggu), P0 (131,34 g/ekor/minggu) dan terendah terdapat pada perlakuan P4 sebesar 116,43 g/ekor/minggu.

Tabel 3 menunjukkan bahwa rata-rata pertambahan bobot badan Itik Porsea secara umum sebesar 130,44 gram/ekor/minggu. Angka tersebut lebih 
rendah daripada pemiliharaan itik peking menurut Pasaribu (2011) yaitu sebesar 177,19 g/ekor/minggu. Hal ini dipengaruhi oleh genetik, nutrisi dan lingkungan ternak. Pemeliharaan dan pengendalian penyakit yang baik terhadap setiap perlakuan menunjukkan pengaruh yang besar terhadap pertambahan bobot badan. Selain itu, nutrisi yang terkandung dalam setiap perlakuan yang diberikan juga sangat berpengaruh terhadap pertambahan bobot badan itik selama penelitian. Hal ini sesuai dengan pernyataan Tomaszewska et al., (1988) yang menyatakan bahwa laju pertumbuhan bobot badan dipengaruhi oleh umur, lingkungan dan genetik. Berat tubuh awal fase penggemukaan berhubungan dengan berat dewasa. Dilanjutkan dengan pernyataan Tillman et al., (1991) yang menyatakan bahwa kuantitas dan kualitas ransum yang diberikan menyangkut dengan tinggi rendahnya produksi dan kecepatan pertumbuhan yang sedang tumbuh. Kualitas ransum erat hubunganya dengan pemilihan bahan-bahan ransum makanan penguat.

Berdasarkan hasil analisis ragam menunjukkan bahwa ransum perlakuan dengan perbedaan tepung ikan dalam level yang sama memberikan pengaruh berbeda nyata $(\mathrm{P}<0,05)$ pada tingkat pertambahan bobot badan Itik Porsea sampai umur 12 minggu.

Hasil uji lanjut dengan Duncan menunjukkan bahwa perlakuan P0, P1, P2 dan P3 berbeda nyata dengan perlakuan P4. Hal ini diasumsikan bahwa peningkatan bobot badan pada perlakuan P0, P1, P2 dan P3 dikarenakan efek dari asam amino yang terkandung dalam tepung ikan komersial lebih komplit dibandingkan dengan asam amino yang terkandung dalam tepung ikan pora-pora. Sehingga pada perlakuan P4 dengan penggunaan 100\% tepung ikan pora-pora rataan pertambahan bobot badan ternak sangat rendah dibandingkan dengan perlakuan yang lain. Hal ini sesuai dengan pernyataan Wahju (2004), yang menyatakan bahwa kebutuhan asam amino dan protein pada ternak dibutuhkan dalam meningkatkan pertambahan bobot badan, untuk hidup pokok serta pertumbuhan jaringan dan bulu.

\section{Konversi Ransum}


Konversi ransum adalah perbandingan jumlah pakan yang dikonsumsi pada waktu tertentu dengan produksi yang dihasilkan (pertambahan bobot badan) dalam waktu yang sama. Konversi ransum adalah indikator teknis yang menggambarkan tingkat efisiensi penggunaan ransum, semakin rendah angka konversi ransum berarti semakin efisien. Data hasil pengamatan konversi ransum itik porsea dapat dilihat pada Tabel 3.

Tabel 3 di atas dapat dilihat bahwa rataan konversi ransum itik porsea selama penelitian adalah 4,06. Hasil analisis ragam menunjukkan bahwa penggunaan tepung ikan pora-pora dengan level yang sama memberikan pengaruh yang tidak berbeda nyata $(\mathrm{P}>0,05)$ terhadap konversi ransum Itik Porsea yakni angka konversi dari kedua perlakuan yang menggunakan tepung ikan pora-pora dari level 2,5\% sampai dengan level 10\% bila dibandingkan dengan perlakuan P0 (tanpa menggunakan tepung ikan pora-pora. Artinya, baik ransum yang menggunakan tepung ikan komersial maupun ransum yang menggunakan tepung ikan pora-pora pada level 2,5\% sampai dengan $10 \%$ tidak memberikan pengaruh yang nyata terhadap konversi ransum Itik Porsea.

\section{KESIMPULAN}

Kesimpulan dari penelitian ini adalah pemanfaatan tepung ikan pora-pora dapat menggantikan tepung ikan komersial sebesar $75 \%$.

\section{DAFTAR PUSTAKA}

BPS Kabupaten Toba Samosir. 2013. Toba Samosir dalam Angka 2013. http://issuu.com/bpstobasa/docs/121_1102001_2013_1206000dda_toba_s.

Dinas Pertanian Karo. 2012. Statistik Kabupaten Karo. Karo. Sumatera Utara

Hartadi, H., S. Reksohardiprojo, dan A.D. Tillman. 1997. Komposisi Bahan Pakan Untuk Indonesia. UGM Press, Yogyakarta.

Kartamihardja, E.S. 2009. Mengenal Ikan Bilih (Mystacoleucus padangensis Bleeker) dan Siklus Hidupnya di Danau Toba. Pusat Riset Perikanan Tangkap. Jakarta.

Laboratorium Ilmu Nutrisi Ternak. 2008. Fakultas Pertanian USU, Medan.

Laboratorium Loka Penelitian Kambing Potong. 2014. Sei Putih. 
National Research Council. 1994. Nutrient Requirements of Poultry. Ninth Revised Edition National Academy of Sciences. Washington, D.C.

North, M.O. dan D.D. Bell. 1990. Commercial Chicken Production Manual. $4^{\text {th }}$ Edition. Van Nostrand. Reinhold, New York.

Parakkasi, A. 1999. Ilmu Gizi dan Makanan Ternak Monogastrik.Angkasa, Bandung.

Pasaribu, M.D. Penggunaan Bungkil Inti Sawit Yang Diberi Hemicell Dalam Ransum Terhadap Performans Itik Raja (Mojosari Alabio) Umur 1-7 Minggu. Skripsi. Universitas Sumatera Utara, Medan.

Piliang W.G. 2000. Fisiologi Nutrisi. Volume I. Institut Pertanian, Bogor.

Sihaloho, R.H. 2014. Pemanfaatan Tepung Ikan Pora-pora dan Limbah Industri Pengolahan Ikan Nila Dalam Ransum Terhadap Performans Ayam Kampung Umur 0-12 Minggu. Skripsi. Universitas Sumatera Utara. Medan.

Tillman. A. D., Hartadi., H. Reksohaddiprodjo. S. Prawirokusumo dan S. Lebdosoekojo. 1991. Ilmu Makanan Ternak Dasar. Gadjah Mada University Press. Yogyakarta.

Tomaszewska, M., T. D. Chaniago and I. K Sutama. 1988. Reproduction in Relation to Animal Production in Indonesia. Institut Pertanian Bogor. Bogor.

Wahju, J. 2004. Ilmu Nutrisi Unggas. Universitas Gadjah Mada Press, Yogyakarta.

Wasito dan Eni S.R., 1994. Beternak Itik Alabio. Kanisius, Yogyakarta.

Williamson G. And W. J. A. Payne, 1993. Pengantar Peternakan di Daerah Tropis. Terjemahan oleh : IGN Djiwa Darmadja. Gadjah Mada University Press. Yogyakarta. 